\title{
Air pollution monitoring with mosses in Western Rhodopes, Bulgaria
}

\author{
N.P. Gribacheva ${ }^{1 *}$, G.M. Gecheva ${ }^{2}$, V.M. Stefanova ${ }^{3}$ \\ ${ }^{1}$ Forest Research Institute, Bulgarian Academy of Sciences, Kliment Ohridski Blvd. 132, 1756 Sofia, Bulgaria, \\ ${ }^{2}$ University of Plovdiv, Faculty of Biology, Tsar Asen Str. 24, 4000 Plovdiv, Bulgaria \\ ${ }^{3}$ University of Plovdiv, Faculty of Chemistry, Tsar Asen Str. 24, 4000 Plovdiv, Bulgaria
}

Received January 17, 2018; Revised January 30, 2019

For the first time a complex study of the bioaccumulation of 22 macro- and microelements, as well as of 18 rare earth and radioactive elements in mosses was applied in the territory of Western Rhodopes. The research is a part of the international program (ICP Vegetation, UNECE) that has been carried out in most of the European countries since 1987. Certain local emitters like old and open mines, serpentines, as well as cross-border transmission were identified. In addition, highest concentrations of radioactive elements were registered in the area of an old uranium mine and most elevated sites, probably due to increased wet deposition. Both heavy metals and toxic elements, as well as radioactive elements maxima were lower than measured highest levels for Bulgaria and Europe. In such studies, inductively coupled plasma spectrometry (ICP-OES, ICP-MS) could be recommended.

Keywords: atmospheric deposition; trace elements; ICP-OES; ICP-MS; NAA

\section{INTRODUCTION}

In recent decades mosses have been successfully used as biomonitors of atmospheric deposition of heavy metals in Europe [1-3].

Western Rhodopes were selected as a research area because they cover a territory of low population density: $28.5 \mathrm{~km}^{2}$ [4], a poorly developed industry and protected areas (about $11 \%)$. At the same time, there is a significant number of old and open mines (Table 1).

Table 1. Geographical and economical characteristics of the sampling sites.

\begin{tabular}{|c|c|c|c|c|c|c|}
\hline \multirow[b]{2}{*}{ No } & \multirow[b]{2}{*}{ Sites } & \multicolumn{2}{|c|}{ Coordinates } & \multirow{2}{*}{$\begin{array}{l}\text { Altitude, } \\
\text { m a.s.l. }\end{array}$} & \multirow[b]{2}{*}{ Industry } & \multirow{2}{*}{$\begin{array}{l}\text { Environmental } \\
\text { protection of } \\
\text { the region }\end{array}$} \\
\hline & & $\mathbf{N}$ & $\mathbf{E}$ & & & \\
\hline 1 & Kiselchovo village & 41.53461 & 24.576694 & 1066 & $\begin{array}{l}\text { Old uranium } \\
\text { mine }\end{array}$ & Natura 2000 \\
\hline 2 & Luki town & 41.76622 & 24.809278 & 1000 & Mine works & Natura 2000 \\
\hline 3 & Rudozem town & 41.50292 & 24.855611 & 930 & Mine works & Natura 2000 \\
\hline 4 & Madan town & 41.46781 & 24.959278 & 788 & Mine works & Natura 2000 \\
\hline 5 & Erma reka village & 41.42085 & 25.036028 & 580 & Tailing pond & Natura 2000 \\
\hline 6 & Svetulka village & 41.56639 & 25.101583 & 705 & Background & \\
\hline 7 & Belite brezi & 41.57831 & 25.161667 & 930 & Background & \\
\hline 8 & $\begin{array}{c}\text { Tsankov kamak } \\
\text { Dam }\end{array}$ & 41.73703 & 24.419722 & 677 & Background & Natura 2000 \\
\hline 9 & Barutin village & 41.59006 & 24.148611 & 1040 & $\begin{array}{l}\text { Old uranium } \\
\text { mine }\end{array}$ & Natura 2000 \\
\hline 10 & $\begin{array}{c}\text { Goliam Beglik } \\
\text { Dam }\end{array}$ & 41.81478 & 24.130528 & 1560 & Background & Natura 2000 \\
\hline 11 & Batak Dam & 41.95022 & 24.147694 & 1143 & Background & Natura 2000 \\
\hline 12 & Yundola & 42.03417 & 23.907444 & 1070 & Background & Natura 2000 \\
\hline 13 & $\begin{array}{l}\text { Momchilovtsi } \\
\text { village }\end{array}$ & 41.65906 & 24.774694 & 1215 & Background & Natura 2000 \\
\hline 14 & Rozhen & 41.67001 & 24.735722 & 1430 & Background & \\
\hline 15 & Bachkovo village & 41.95001 & 24.868944 & 425 & Background & Natura 2000 \\
\hline
\end{tabular}

* To whom all correspondence should be sent: 
The combination of background and impacted sites, as well as the lack of data on pollutant deposition, determined the interest in a comprehensive study and the selection of the Western Rhodopes as a region for implementing the biomonitoring approach with mosses.

\section{MATERIALS AND METHODS}

The sampling net includes fifteen sites in the region of Western Rhodopes $\left(8732 \mathrm{~km}^{2}\right)$ : two sites near to old uranium mines (No 1, No 9, Table 1), three in the range of lead-zinc mines (No 2, No 3, No 4), one to a tailing pond (No 5) and nine were accepted as background sites in the initial analysis of the potential sources of impact (No 6, No7, No 8, No 10 , No 11, No 12, No 13, No 14, No 15).

Sampling was carried out during the dry season of summer 2015. Hypnum cupressiforme Hedw. was collected at 14 sites. At one site (Barutin village, No 9), a representative sample could only be formed by Homalothecium lutescens (Hedw.) H.Rob.

The moss sampling followed the requirements of the ICP-V manual [5]: each sample consisted of up to 5 sub-samples after the standardized European methodology. Sampling, transport, storage and pre-treatment followed the methodological recommendations of the European Program [6].

The treatment of the moss samples included the following procedures. The samples were carefully cleaned from mechanical particles and other organic material, dried at $40^{\circ} \mathrm{C}$ and wet-ashed. About $1 \mathrm{~g}$ of moss material was treated with nitric acid (65\%) overnight, followed by addition of $2 \mathrm{ml}$ portions of hydrogen peroxide. Samples were sealed and irradiated in Milestone Ethos One microwave digestion system. A portion of moss reference material (M2 or M3) was digested together with every sample series and corresponding blank samples were prepared as well.

The elements $\mathrm{P}, \mathrm{K}, \mathrm{Ca}, \mathrm{S}, \mathrm{Na}, \mathrm{Mg}, \mathrm{Mn}, \mathrm{Fe}, \mathrm{Al}$, $\mathrm{Zn}, \mathrm{Cu}, \mathrm{Pb}$ and $\mathrm{Sr}$ were determined by inductively coupled plasma atomic emission spectrometry (ICP-OES) using iCAP 6300 Duo, Thermo Scientific, carried out in the Department of Analytical and Computer Chemistry, Faculty of Chemistry, University of Plovdiv. The elements Cr, $\mathrm{Co}, \mathrm{Cd}, \mathrm{V}, \mathrm{Ni}, \mathrm{As}, \mathrm{Hg}, \mathrm{Se}$ and $\mathrm{Sb}$ were determined by ICP-MS (Agilent 7700).

The calibration solutions for both methods of analysis (ICP-OES and ICP-MS), were prepared by appropriate dilution of Merck stock solutions: ICP multi-element standard solution IV (23 elements in dilute nitric acid, $1000 \mathrm{mg} \mathrm{L}^{-1}$ Certipur () and respectively for ICP-MS multi-element standard solution VI (30 elements in dilute nitric acid Certipur $($ ). For the ICP-OES analysis spectral-free analytical lines of the following elements were selected: $\mathrm{Na}(589.592 \mathrm{~nm}) ; \mathrm{K}(766.490 \mathrm{~nm}) ; \mathrm{Mg}$ $(285.213 \mathrm{~nm}) ; \mathrm{Ca}(422,673 \mathrm{~nm}) ; \mathrm{Zn}(202.548 \mathrm{~nm})$; Mn (257,610 nm); Fe (238,204 nm); Al (167.079 $\mathrm{nm}) ; \mathrm{Cu}(324.754 \mathrm{~nm}) ; \mathrm{Sr}(421.552 \mathrm{~nm}) ; \mathrm{Pb}$ $(220.353 \mathrm{~nm})$; P $(177.495 \mathrm{~nm})$ and $\mathrm{S}(182.034 \mathrm{~nm})$. Measurements were performed by axial plasma monitoring.

Two measurement modes were used to determine trace elements by ICP-MS. In the standard mode (without collision gas), the signals of ${ }^{51} \mathrm{~V},{ }^{111} \mathrm{Cd}$ and ${ }^{202} \mathrm{Hg}$ were measured. A collision cell (operating with 4,8 $\mathrm{ml} . \mathrm{min}^{-1} \mathrm{He}$ ) was applied to eliminate spectral matrix-induced polyatomic interferences for determination of ${ }^{52} \mathrm{Cr},{ }^{59} \mathrm{Co},{ }^{62} \mathrm{Ni}$, ${ }^{75} \mathrm{As},{ }^{78} \mathrm{Se}$ and ${ }^{121} \mathrm{Sb}$. Rh was added to all samples and calibrants as an internal standard for dynamic correction of the non-spectral matrix effect during ICP-MS analysis.

For quality assurance purposes moss reference materials $\mathrm{M} 2$ and $\mathrm{M} 3$ were applied [7, 8]. All concentrations were presented as $\mathrm{mg} \mathrm{kg}^{-1}$ dry weight.

The elements $\mathrm{Na}, \mathrm{Mg}, \mathrm{Al}, \mathrm{Cl}, \mathrm{K}, \mathrm{Ca}, \mathrm{Sc}, \mathrm{Ti}, \mathrm{V}$, $\mathrm{Cr}, \mathrm{Mn}, \mathrm{Fe}, \mathrm{Ni}, \mathrm{Co}, \mathrm{Zn}, \mathrm{I}, \mathrm{Ba}, \mathrm{Cs}, \mathrm{La}, \mathrm{Ce}, \mathrm{Sm}, \mathrm{Tb}$, $\mathrm{Tm}, \mathrm{Hf}, \mathrm{Ta}, \mathrm{W}, \mathrm{Th}, \mathrm{U}$ were determined by neutron activation analysis (NAA). The analysis was performed at the pulsed fast reactor IBR-2 at the Frank Laboratory of Neutron Physics, Joint Institute for Nuclear Research, Dubna, Moscow Region, Russia. At the laboratory the samples were cleaned from extraneous plant material and airdried to constant weight at $30 \div 40^{\circ} \mathrm{C}$ for $48 \mathrm{~h}$. The samples were not washed and not homogenised. The concentrations are presented as $\mathrm{mg} \mathrm{kg}^{-1}$ dry weight.

Principal component analysis (PCA) in programme CANOCO was used to study relationships between the different elements in each site [9]. The element concentrations were divided by their standard deviation and PCA was speciescentered. The spatial trends were assessed. The maps were produced using ArcMAP, part of ArcGIS, an integrated geographical information system (GIS) and display the mean element concentration per $50 \times 50 \mathrm{~km}^{2}$ EMEP grid cell $[8$, $10]$.

\section{RESULTS AND DISCUSSION}

From the group of macroelements in moss tissues $\mathrm{Ca}, \mathrm{K}, \mathrm{Al}$ and $\mathrm{P}$ dominated, while $\mathrm{Pb}$ was in the highest amount as microelement. The difference 
N.P. Gribacheva et al.: Air pollution monitoring with mosses in Western Rhodopes, Bulgaria

between $\mathrm{Pb}$ levels in the regions of open and old mines (No 1-5; No 9) in comparison with more pristine sites was more than 60 times, while for $\mathrm{Cd}$ it was 5 times (Fig. 1).

PCA showed that the first axis (eigenvalue 0.420) correlated with 12 macro- and microelements, while the second axis was positively correlated $(0.200)$ with macroelements $\mathrm{K}$, $\mathrm{Mg}, \mathrm{Mn}, \mathrm{P}$ and $\mathrm{S}$. In the lower left part of the ordination plot were located sites with significant anthropogenic impact (No 2-5; No 15) and increased atmospheric deposition, in particular of strontium, lead, cadmium and zinc (Fig. 2) Additionally a serpentine small spot - site № 6, in the region of Svetulka village, joined this group of hotspots. Two potential background sites (No 10, 14) with highest altitude, located in a similar longitude line, were affected by transboundary pollution, also known as the Southeastern European gradient (at the upper left part of the ordination). With lowest pollutant deposition were two sampling sites in the western part of the sampling net, near Barutin and Batak villages (upper right of Fig. 2). Comparison with data for the same elements and sites from the previous year [4] showed that in 2015 higher levels were found for 4 elements: $\mathrm{Co}, \mathrm{Fe}, \mathrm{Hg}$ and $\mathrm{Ni}$. a)

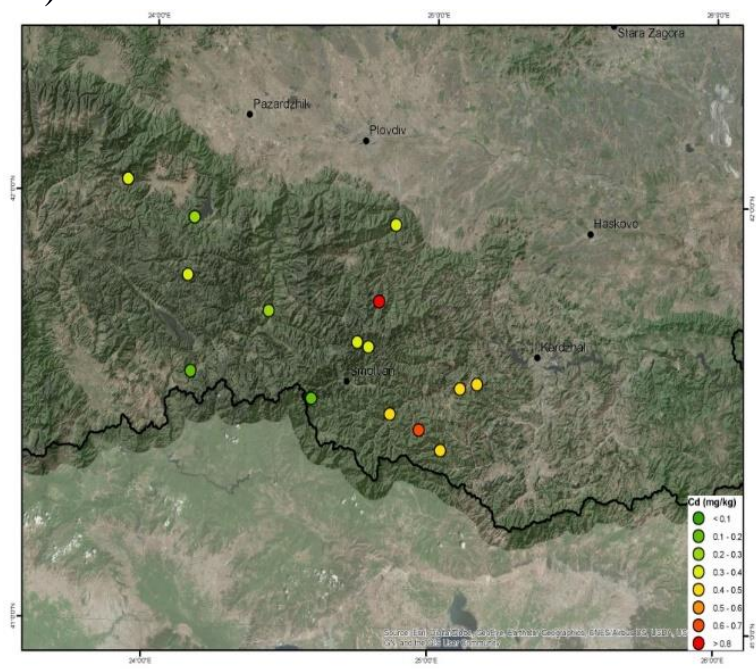

b)

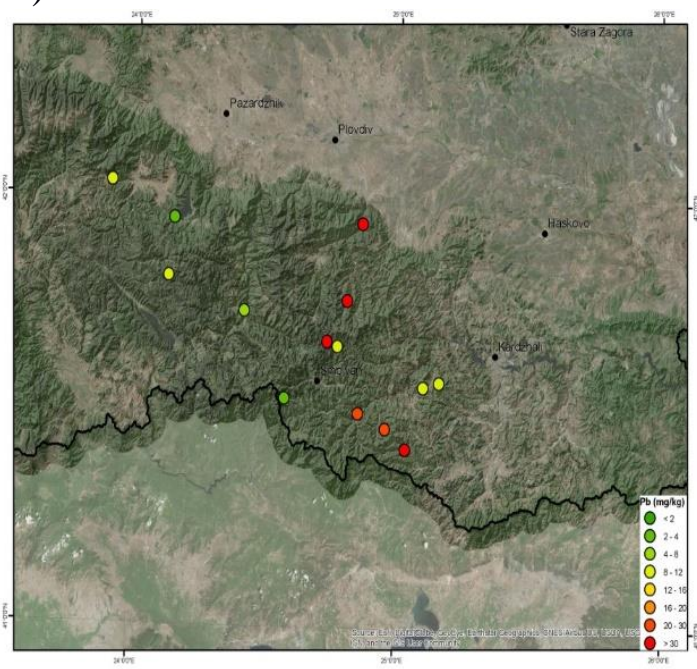

Fig. 1. Element concentration in mosses in Western Rhodopes, Bulgaria for a) cadmium, b) lead.

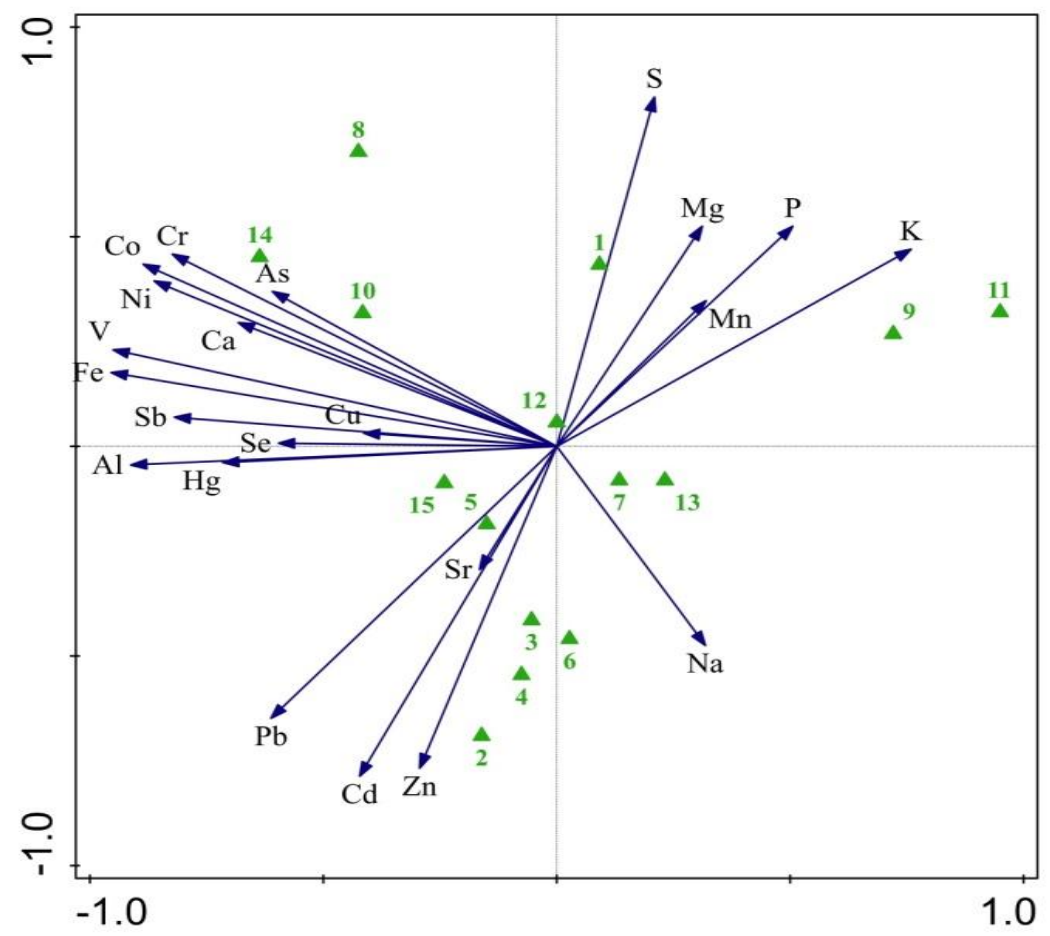

Fig. 2. PCA-ordination diagram of studied sites and analysed elements. 
N.P. Gribacheva et al.: Air pollution monitoring with mosses in Western Rhodopes, Bulgaria

Comparison with heavy metals and toxic elements ( $\mathrm{Al}, \mathrm{As}, \mathrm{Cd}, \mathrm{Cr}, \mathrm{Cu}, \mathrm{Fe}, \mathrm{Ni}, \mathrm{Pb}, \mathrm{V}, \mathrm{Zn}$ ) deposition in Europe [3] illustrated lower element accumulation in mosses in Western Rhodopes. Nevertheless, elements' medians from the studied region were higher than medians for both Bulgaria and Europe, except for copper.

Among the rest of the analyzed elements, more pronounced was the variation of U (32 times), followed by Hf (23 times) and Sc (19 times), Cs and $\mathrm{W}$ (16 times), Th (14 times), Sm and Tb (13 times), Ta (12 times), La (10 times), No Tm (8 times), $\mathrm{Ti}, \mathrm{Ba}$, и $\mathrm{Ce}$ (7 times), $\mathrm{Cl}$ (4 times), $\mathrm{Br}$ and $\mathrm{Rb}$ (5 times) and I (3 times) (Table 2). A positive correlation was assessed between bioaccumulation of Th and $U\left(R^{2}=0.957\right)$.

Table 2. Minimum, maximum concentrations and median of radioactive and rare earth elements.

\begin{tabular}{|c|c|c|c|}
\hline $\begin{array}{l}\text { Element, } \\
\mathrm{mg} \mathrm{kg}^{-1}\end{array}$ & Minimum & Maximum & Median \\
\hline $\mathrm{Cl}$ & 50.2 & 211 & 100 \\
\hline $\mathrm{Sc}$ & 0.042 & 0.83 & 0.29 \\
\hline $\mathrm{Ti}$ & 25 & 303 & 106 \\
\hline $\mathrm{Br}$ & 0.90 & 4.4 & 2.5 \\
\hline $\mathrm{Rb}$ & 5.2 & 26.5 & 9.6 \\
\hline $\mathrm{I}$ & 0.63 & 1.6 & 1.2 \\
\hline $\mathrm{Ba}$ & 15.5 & 103 & 44.8 \\
\hline Cs & 0.05 & 0.81 & 0.36 \\
\hline $\mathrm{La}$ & 0.23 & 2.2 & 0.83 \\
\hline $\mathrm{Ce}$ & 0.6 & 4.2 & 1.77 \\
\hline $\mathrm{Sm}$ & 0.03 & 0.38 & 0.134 \\
\hline $\mathrm{Tb}$ & 0.004 & 0.05 & 0.018 \\
\hline $\mathrm{Tm}$ & 0.004 & 0.03 & 0.014 \\
\hline $\mathrm{Hf}$ & 0.013 & 0.3 & 0.106 \\
\hline $\mathrm{Ta}$ & 0.006 & 0.07 & 0.024 \\
\hline $\mathrm{W}$ & 0.02 & 0.32 & 0.093 \\
\hline Th & 0.05 & 0.68 & 0.21 \\
\hline $\mathrm{U}$ & 0.012 & 0.38 & 0.073 \\
\hline
\end{tabular}

Maxima of 7 of the above elements ( $\mathrm{Sc}, \mathrm{Ti}, \mathrm{Cs}$, $\mathrm{Ce}, \mathrm{Sm}, \mathrm{Tb}$ and $\mathrm{W}$ ) were found in mosses from Golyam Beglik Dam, 6 in the area of an old uranium mine (U, Th, Ba, I, Rb, Br) and 3 (Tm, Hf and $\mathrm{Ta}$ ) in the potential background Rozhen region. High values in mosses in both potential background sites (Golyam Beglik and Rozhen) could be linked to increased radioactive deposition with elevation due to higher wet deposition.

Maximum measured $U$ concentration was 17 times lower than $U$ values for Bulgaria, detected in $2005\left(6.23 \mathrm{mg} \mathrm{kg}^{-1)}[11]\right.$ and about 4 times lower than maximum for neighboring FYRM. High $U$ values were registered also in samples from Rozhen $\left(0.30 \mathrm{mg} \mathrm{kg}^{-1}\right)$ and Tsankov kamak Dam $(0.25 \mathrm{mg}$ $\left.\mathrm{kg}^{-1}\right)$.

Thorium maximum level was 34 times lower than the maximum value for the country of $23 \mathrm{mg}$ $\mathrm{kg}^{-1}$ and 11 times lower than in FYRM $\left(7.6 \mathrm{mg} \mathrm{kg}^{-}\right.$ $\left.{ }^{1}\right)$.

Caesium maximum in the studied region was 7 times lower in comparison with the maximum for Bulgaria (5.71 mg kg-1) and 22 times lower than the maximum in Serbia (18.2 $\left.\mathrm{mg} \mathrm{kg}^{-1}\right)$ [10].

Highest concentrations of $\mathrm{U}$ and $\mathrm{Th}$ were found in moss samples from an old uranium mine near Kiselchovo village; maximum of Cs was analyzed determined in moss tissues at the region of Golyam Beglik Dam. Minimum levels for cesium were found in the Barutin village; for thorium and uranium in the samples from Batak Dam.

\section{CONCLUSIONS}

Presence of natural geochemical anomalies for Western Rhodopes, mainly associated with accumulation of minerals, was illustrated by hotspots near open way of mining and old mines. Despite lower maximum concentration in the studied region compared to those for Bulgaria and Europe in 2010, medians of all 10 heavy metals and toxic elements except $\mathrm{Cu}$ were higher.

Measured maximum values of $\mathrm{U}$, Th and Cs were lower than maximum levels for Bulgaria and neighboring countries.

Based on the results, inductively coupled plasma techniques (ICP-OES, ICP-MS) could be recommended because they permit to analyze macroelements with an important physiological role such as $\mathrm{Mg}, \mathrm{Na}$ and micro elements as $\mathrm{Sb}$ and $\mathrm{Sr}$ with sufficient accuracy.

Annual sampling at each sampling point for three consecutive years could be recommended in regions with lack of previous data, significant elevation changes and with local emission sources. This will ensure analysis of tendencies and will reveal average pollutant levels.

Acknowledgment: We would like to thank Prof. Marina Frontasyeva, United Institute for Nuclear Research (JINR), Dubna, Russian Federation, for the conducted NAA of moss samples.

\section{REFERENCES}

1. H.G. Zechmeister, K. Grodzinkska, G. SzarekLukaszewska. Principles, concepts and applications. Elsevier, Amsterdam, The Netherlands, ISBN 0-08044177-7, 2003, p. 329.

2. H. Harmens, D.A. Norris, G.R. Koerber, A. Buse, E. 
N.P. Gribacheva et al.: Air pollution monitoring with mosses in Western Rhodopes, Bulgaria

Steinnes, Å. Rühling. Atmos. Environ., 41, 6673 (2007).

3. H. Harmens, D.A. Norris, D. Cooper, J. Hall and the participants of the moss survey. Programme Coordination Centre for the ICP Vegetation, Centre for Ecology and Hydrology, Bangor, UK. http://icpvegetation.ceh.ac.uk, 2008.

4. G. Gecheva, N. Gribacheva, L. Yurukova†, V. Stefanova, V. Kmetov, M. Frontasyeva, G. Popgeorgiev. Atmospheric pollution assessment with mosses in Western Rhodopes, Bulgaria, $J$. BioSci. Biotechnol., 5(2), 125 (2016).

5. M. Frontasyeva, H. Harmens, the participants of the ICP Vegetation, 2014, Heavy metals, nitrogen and POPs in European mosses: 2015 survey, Monitoring Manual.

6. ICP Vegetation (2010), Heavy metals in European mosses: 2010 survey. Monitoring manual, ICP Vegetation Programme Coordination Centre, CEH Bangor, UK. http://icpvegetation.ceh.ac.uk.

7. E. Steinnes, A. Rühling, H. Lippo, A. Mäkinen, Accred. Qual.Assur., 2, 243 (1997).

8. H. Harmens, D.A. Norris, E. Steinnes, E. Kubin, J. Piispanen, R. Alber, Y. Aleksiayenak, O. Blum, M. Coşkun, M. Dam, L. De Temmerman, J.A.
Fernández, M. Frolova, M. Frontasyeva, L. González-Miqueo, K. Grodzinska, Jeran, S. Korzekwa, M. Krmar, K. Kvietkus, S. Leblond, S. Liiv, B. Mankovská, R. Pesch, Å. Rühling, J.M. Santamaria, W. Schröder, Z. Spiric, I. Suchara, L Thöni, V. Urumov, L. Yurukova, H.G. Zechmeister, Environ. Pollut., 158, 3144 (2010).

9. C.J.F. Ter Braak, P. Smilauer. CANOCO reference manual and CanoDraw for Windows user's guide: software for canonical community ordination (version 5). Microcomputer Power, Ithaca, New York, 2002.

10. H. Harmens, D.A. Norris, D. Cooper, G. Mills, E. Steinnes, E. Kubin, L. Thöni, J.R. Aboal, R. Alber, A. Carballeira, M. Coșkun, L. De Temmerman, M. Frolova, L. Gonzáles-Miqueo, Z. Jeran, S. Leblond, S. Liiv, B. Mankovská, R. Pesch, J. Poikolainen, Å. Rühling, J. M. Santamaria, P. Simonèiè, W. Schröder, I. Suchara, L. Yurukova, H. G. Zechmeister, Environ. Pollut., 159, 2852 (2011).

11. S. Marinova, L. Yurukova, M. Frontasyeva, E. Steinnes, L. Strelkova, A. Marinov, A. Karadzinova, Ecol. Chem. Eng., 17, 37 (2010).

12. B. Smodiš, A. Bleise, J. Radioanal. Nucl. Chem., 271, 269 (2007). 